\title{
Morphometric study of the postnatal growth of the parotid gland of the mouse
}

\section{Estudo morfométrico do crescimento pós-natal da glândula parótida do camundongo}

\author{
Tiago Turri de Castro Ribeiro* \\ André Dotto Sottovia** \\ Tania Mary Cestari*** \\ Rumio Taga****
}

\begin{abstract}
The growth of the mouse parotid glands during 7 and 35 days of postnatal life was studied by morphometric methods. The mass of the gland, the volume of each morphological compartment, and the cell number in each compartment were evaluated. The data obtained for each evaluated dimension were adjusted by an exponential equation, of the type $\mathrm{Y}=\mathrm{a} \cdot \mathrm{e}^{\mathrm{K} . \mathrm{x}}$, thus permitting the calculation of their mean duplication time $\left(\mathrm{T}_{\mathrm{D}}\right)$, i.e., an estimation of their growth rate. Analysis of the results showed a marked 1,424\% increase in the gland mass during the whole studied period, with $\mathrm{T}_{\mathrm{D}}=7.10$ days. This growth occurred by increases in absolute volume of acini, intercalated ducts, striated ducts, excretory ducts and stroma, with percentual increases of 3,048\%, 417\%, 2,662\%, $2,594 \%$ and $367 \%$, respectively, and $\mathrm{T}_{\mathrm{Ds}}$ of $5.62,11.71,5.55,5.47$ and 14.45 days, respectively. Analysis of the cell number growth in each compartment showed increases of $1,904 \%, 285 \%, 1,228 \%, 1,090 \%$ and $286 \%$, respectively, and $\mathrm{T}_{\mathrm{Ds}}$ of $6.62,20.40,7.19,7.26$ and 14.51 days, respectively. Based on the present results, we concluded that the growth of the mouse parotid glands from day 7 to day 35 of age occurred by intense cell accumulation, mainly in the acini, striated ducts and excretory ducts, with a growth rate sensibly higher than that of the intercalated ducts and stroma.
\end{abstract}

DESCRIPTORS: Parotid gland; Growth and embryonic development; Regression analysis; Histology; Animals.

RESUMO: O crescimento das glândulas parótidas do camundongo durante 7 e 35 dias de vida pós-natal foi estudado por métodos morfométricos. A massa glandular, o volume de cada compartimento morfológico e o número de células em cada compartimento foram avaliados. Os dados obtidos para cada dimensão avaliada foram ajustados por equação exponencial, tipo $\mathrm{Y}=\mathrm{a} \cdot \mathrm{e}^{\mathrm{k} \cdot \mathrm{x}}$, permitindo o cálculo do seu tempo de duplicação médio $\left(\mathrm{T}_{\mathrm{D}}\right)$, ou seja, uma estimativa da sua velocidade de crescimento. A análise dos resultados mostrou a ocorrência de um marcante aumento de massa glandular no período estudado de $1.424 \%$, com $\mathrm{T}_{\mathrm{D}}=7,10$ dias. Esse crescimento glandular ocorreu por aumentos nos volumes absolutos dos ácinos, dos ductos intercalares, dos ductos estriados, dos ductos excretores e do estroma, com aumentos percentuais de, respectivamente, $3.048 \%, 417 \%, 2.662 \%, 2.594 \%$ e $367 \%$, e $\mathrm{T}_{\mathrm{Ds}}$ de $5,62,11,71,5,55,5,47$ e 14,45 dias. A análise da evolução do número de células em cada compartimento demonstrou aumentos de, respectivamente, 1.904\%, 285\%, 1.228\%, 1.090\% e 286\% e $\mathrm{T}_{\mathrm{Ds}}$ de $6,62,20,40,7,19$, 7,26 e 14,51 dias. Baseados nos resultados aqui obtidos, concluímos que o crescimento das glândulas parótidas do camundongo entre os dias 7 e 35 de idade ocorre por intenso acúmulo de células, principalmente nos ácinos e nos ductos estriados e excretores, com uma velocidade de crescimento sensivelmente maior que nos ductos intercalares e no estroma.

DESCRITORES: Glândula parótida; Crescimento e desenvolvimento do embrião; Análise de regressão; Histologia; Animais.

\section{INTRODUCTION}

In contrast with the significant number of autoradiographic and/or morphometric studies on the postnatal development of the rat parotid glands ${ }^{3,5-7,10,15,17}$, no studies on mice exist. Since the parotid glands of adult mice have been widely used for the study of the mechanisms of glandu-

\footnotetext{
* Scientific Initiation Student, Department of Biological Sciences; ***Doctorate Student in Oral Biology, Department of Stomatology; ${ }^{* * *} \mathrm{PhD}$, Chairman, Laboratory of Histology, Department of Biological Sciences - School of Dentistry of Bauru, University of São Paulo.

** Doctorate Student in Oromaxillofacial Surgery and Traumatology, School of Dentistry of Araçatuba, São Paulo State University.
} 
Ribeiro TTC, Sottovia AD, Cestari TM, Taga R. Morphometric study of the postnatal growth of the parotid gland of the mouse. Braz Oral Res 2006;20(1):13-20.

lar growth induced by isoproterenol ${ }^{8,9}$, the understanding of normal mouse parotid gland growth during postnatal development is important.

Therefore, in the present study the course of the cell populations in the different structures of the parotid glands of male mice, as well as their dimensional changes, were analyzed morphometrically during the period from 7 to 35 days of age, and the growth parameters were calculated.

\section{MATERIAL AND METHODS}

Thirty male Swiss mice were divided into groups aged $7,14,21,28$ and 35 days ( 6 mice/group). The litters were maintained with their dams up to the $21^{\text {st }}$ day of age, when they were weaned. All glands were collected always from $11 \mathrm{~h} 00$ to $12 \mathrm{~h} 00$ a.m. to avoid circadian cycle variations. This study was performed following the guidelines for laboratory animal experimentation established by the institution.

The mice were anesthetized with ketamine hydrochloride (10 mg/ $100 \mathrm{~g}$ of body weight) (Agribands do Brasil Ltda., Paulínea, Brazil) plus xylazine hydrochloride (1 mg/100 g of body weight) (Agribands do Brasil Ltda., Paulinea, Brazil), and the body mass of each animal was assessed. The parotid glands of each animal were then removed and its fresh mass was determined. The glands were fixed in 10\% phosphate buffered formalin (Merck KGaA, Darmstadt, Germany) for 1 week, dehydrated in ethyl alcohol (Merck KGaA, Darmstadt, Germany), cleared in xylene (Merck KGaA, Darmstadt, Germany) and embedded in paraffin plus plastic resin (Merck KGaA, Darmstadt, Germany). Five-micrometer thick alternating sections were cut and stained with hematoxylin-eosin (Merck KGaA, Darmstadt, Germany).

\section{Determination of the processed glandular volume}

The processed gland volume (Vp) was calculated based on the fresh mass of the organ $(\mathrm{m})$, its density $(\delta)$ and the retraction factor due to histological processing (fr), using the formula:

$$
\mathrm{Vp}=\mathrm{m} / \delta \times \mathrm{fr} .
$$

Gland density $(\delta)$ was determined in 30 animals, subdivided into five groups of $7,14,21,28$ and 35 days of age, with a precision scale equipped with accessories for the determination of density (Mettler-Toledo GmbH, Greifensee, Switzerland). The retraction caused by histological processing was determined in 6 animals per age group as described by Taga, Sesso ${ }^{16}$ (1978).

\section{Morphometric determination of volume density, total volume and absolute cell number for each glandular structure}

These morphometric measurements were obtained using a $100 \mathrm{X}$ immersion objective and a Zeiss Kpl 8 X eyepiece containing a Zeiss II integration grid (Carl Zeiss Jena GmbH, Jena, Germany) with 10 parallel lines and 100 points in a quadrangular area. The image of the grid was successively superimposed on 50 histological fields per animal, selected by systematic sampling, and the volume density (Vvi), total volume (Vti) and absolute number of cells (Ni) for each glandular structure were determined as indicated by Aherne, Dunnill ${ }^{1}$ (1982).

\section{Statistical analysis}

The stereologic data were compared between age groups by analysis of variance (ANOVA) and a paired multiple comparison procedure (StudentNewman-Keuls test) using the SigmaStat software - Jandel Scientific (Jandel Corporation, Chicago, USA), with the level of significance set at $\mathrm{P}=0.05$ and $P=0.01$. The data of glandular mass, total volume and total number of cells were fitted by an equation of the type:

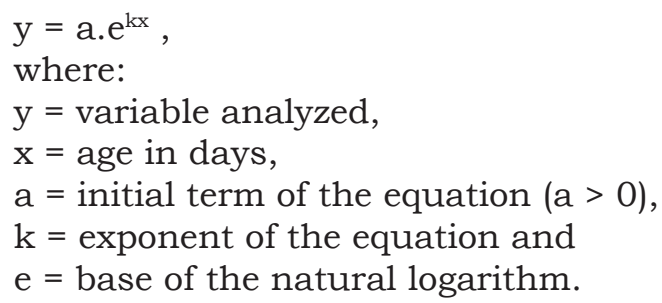

The quality of the fitted data was verified by the coefficient of determination $\left(\mathrm{r}^{2}\right)$. The duplication time $\left(\mathrm{T}_{\mathrm{D}}\right)$ of each fitted dimension was calculated using the formula:

$\mathrm{T}_{\mathrm{D}}=\ln 2 / \mathrm{k}$, where,

$\ln 2=$ is the natural logarithm of 2 and $\mathrm{k}=$ is the coefficient of the equation ${ }^{13}$.

\section{RESULTS}

\section{Morphological results}

At 7 days of age (Figure 1a), the parotid glands were small, but already showed all epithelial struc- 
Ribeiro TTC, Sottovia AD, Cestari TM, Taga R. Morphometric study of the postnatal growth of the parotid gland of the mouse. Braz Oral Res 2006;20(1):13-20.
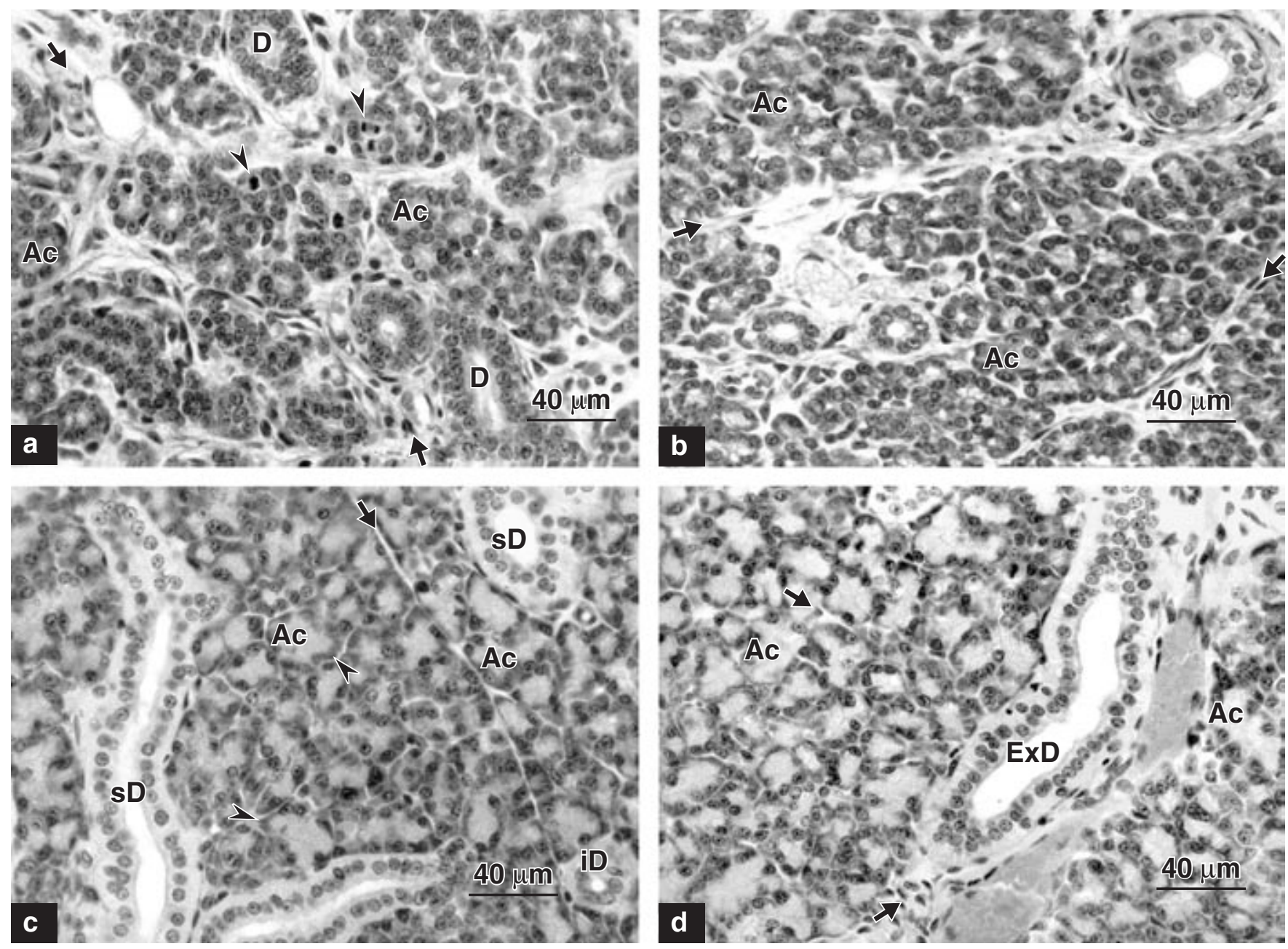

FIGURE 1 - Mouse parotid gland: a) day 7, immature acini (Ac) and ducts (D) surrounded by abundant stroma (arrows) and mitotic figures (arrowheads); b) day 14, increase in the number of acini (Ac) and reduction of stroma (arrows) compared to day 7 (a); c) day 21, mature acini (Ac) with characteristic basal basophilia (arrowhead) and reduced stroma (arrow). Striated ducts (sD) and intercalated duct (iD); and d) day 35, the image is similar to that observed at day 21, with mature acini (Ac), excretory duct (ExD) and reduced stroma (arrows) (H. E.).

tures present in the adult animal - acini, intercalated ducts, striated ducts and excretory ducts - although still completely immature. The stroma was abundant and consisted of loose connective tissue. The interlobular and interlobar septa were found to be in the early phase of organization. Numerous mitotic figures were observed in all morphological compartments.

At 14 days of age (Figure 1b), the lobules were larger and showed a marked increase in the number of acini and a significant reduction in intralobular connective tissue. The interlobular and interlobar septa were well organized. The acini and striated and excretory ducts seemed to have increased in size. A significant number of mitotic figures was also observed.
In the 21-day age group (Figure 1c), the lobules were still large and a reduction in the intralobular connective spaces due to an increase in the number and size of now more irregular acini was observed. The striated ducts, with a morphology close to that of the adult animal, were seen long, with a wide lumen, and consisted of prismatic cells already exhibiting the characteristic longitudinal striations in the basal third and central spherical nuclei. The intercalated ducts, with defined morphology, were short and consisted of short cubic cells with little cytoplasm delimiting a very small, not always visible lumen.

At 28-35 days of age (Figure 1d), no significant alterations were observed compared to the previous age group, except for a reduction in the interlobular stroma. 
Ribeiro TTC, Sottovia AD, Cestari TM, Taga R. Morphometric study of the postnatal growth of the parotid gland of the mouse. Braz Oral Res 2006;20(1):13-20.

\section{Morphometric results}

The course of body and fresh gland mass (a), volume density (b), absolute volume (c) and absolute number of cells (d) of the various morphological compartments of the mouse parotid glands from days 7 to 35 of postnatal life is shown in Graph 1.

Statistical "F" analysis for the body mass data, presented in Graph 1a, showed a progressive body mass gain of $472 \%(P<0.01)$ from day

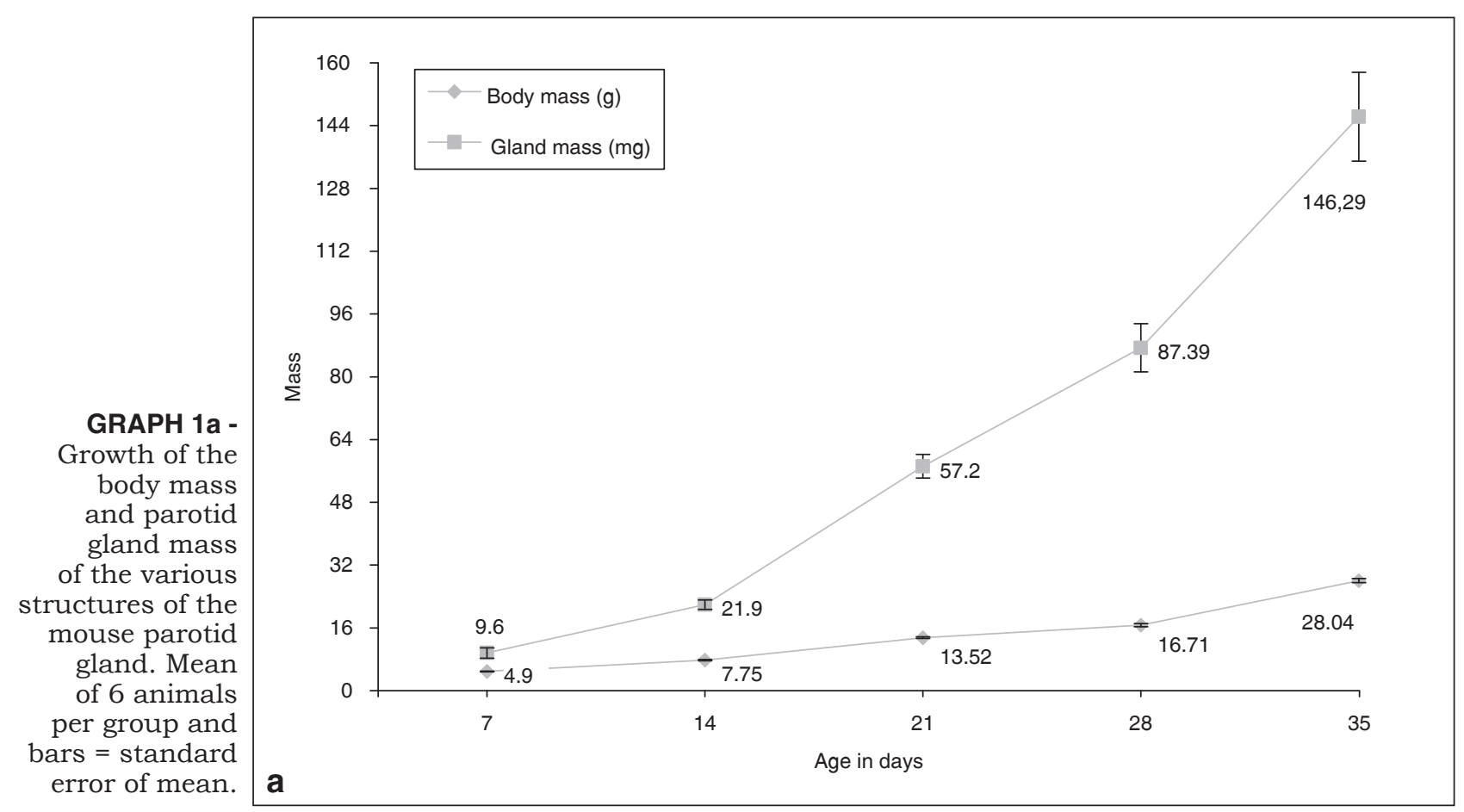

GRAPH 1b -

Course of the volume density of the various structures of the mouse parotid gland. Legends: ID (Intercalated duct), SD

(Striated duct), ExD (Excretory duct) and St (stroma). Mean of 6 animals per group and bars $=$ standard error of mean.

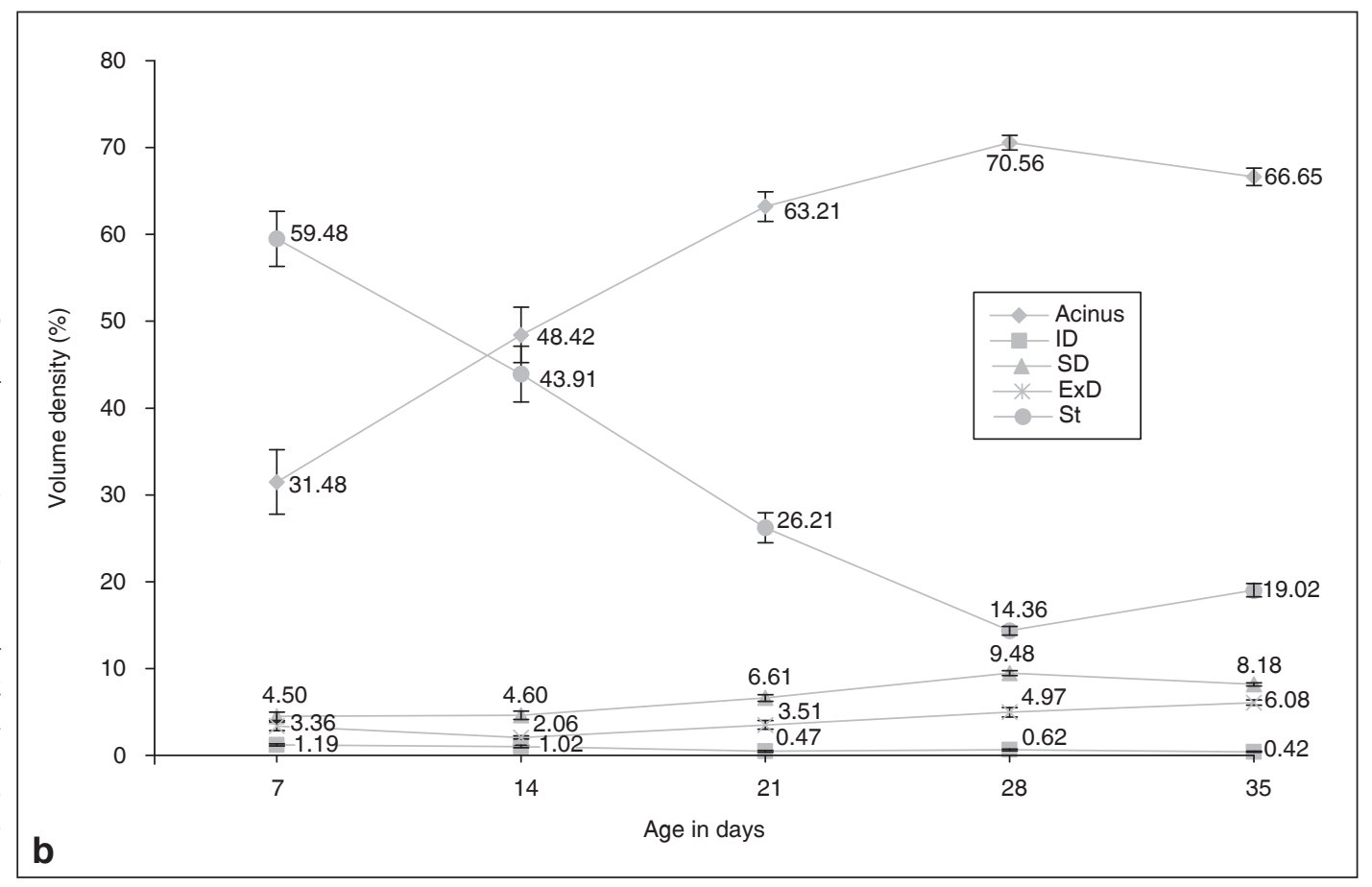


7 to day 35 of age, ranging from $4.9 \pm 0.08 \mathrm{~g}$ at 7 days to $28.0 \pm 0.51 \mathrm{~g}$ at 35 days. The equation obtained to mathematically express this growth was: $\mathrm{Y}=3.33 \mathrm{e}^{(0.060513 \mathrm{x})}$. The calculated duplication time $\left(\mathrm{T}_{\mathrm{D}}\right)$ was 11.45 days, i.e., body mass doubled every 11.45 days during the period analyzed.

In addition, the fresh gland mass data (Graph 1a) also showed a monophasic and progressive growth during the same period with a percental gain of $1,424 \%(\mathrm{P}<0.01)$, from $9.6 \pm 1.30 \mathrm{mg}$ at 7 days to $146.3 \pm 11.31 \mathrm{mg}$ at 35 days of age. The equation obtained was: $\mathrm{Y}=5.59 \mathrm{e}^{(0.097593 \mathrm{x})}$ and $\mathrm{T}_{\mathrm{D}}$ was 7.10 days, i.e., parotid gland mass doubled every 7.10 days during the period.

The course of the volume density of each glandular morphological compartment, from day 7 to day 35 (Graph 1b), and the analysis of variance revealed an increase in volume density of the acini from $31.5 \%$ on day 7 to $70.6 \%$ on day $28(\mathrm{P}<0.01)$, which decreased to $66.6 \%$ on day $35(\mathrm{P}<0.05)$. The intercalated ducts showed a decrease from $1.2 \%$ at 7 days to $0.5 \%$ at 21 days $(\mathrm{P}<0.01)$, remaining stable thereafter $(\mathrm{P}>0.05)$. The volume fraction occupied by the striated ducts increased from $4.6 \%$ at 14 days to $9.5 \%$ at 28 days $(\mathrm{P}<0.01)$, with stabilization being observed thereafter $(\mathrm{P}>0.05)$. The excretory ducts showed an increase from $2.1 \%$ to $5.0 \%(\mathrm{P}<0.01)$ only during the period from 14 to 28 days. Volume density of the stroma decreased progressively from $59.5 \%$ on day 7 to $14.4 \%$ on day $28(\mathrm{P}<0.01)$ and increased to $19.0 \%$ on day $35(\mathrm{P}<0.01)$.

On the other hand, the absolute volume of all morphological compartments increased significantly from day 7 to day 35 (Graph 1c). The percental increases were 3,048\%, 417\%, 2,662\%, $2,594 \%$ and $367 \%$ for the acini, intercalated ducts, striated ducts, excretory ducts and stroma, respectively ( $\mathrm{P}<0.01$ for all compartments).

Regression analysis showed good fits of the data of all morphological compartments to the exponential equations. These equations and their respective coefficients of determination are shown in Table 1. Based on these equations, the volumetric $\mathrm{T}_{\mathrm{D}}$ for each compartment was calculated, which, in this case, represents an estimate of the rate in volume gain of the compartment, i.e., the lower the $\mathrm{T}_{\mathrm{D}}$, the higher the compartmental growth rate. The duplication times in increasing order were 5.47 , $5.55,5.62,11.71$ and 14.45 days for the excretory ducts, striated ducts, acini, intercalated ducts and stroma, respectively.

The absolute number of cells in each morphological compartment of the mouse parotid glands from days 7 to 35 is shown in Graph 1d. Analysis of variance revealed a marked increase in all cell populations during the period from day 7 to day 35. Percental growth was 1,904\%, 285\%,

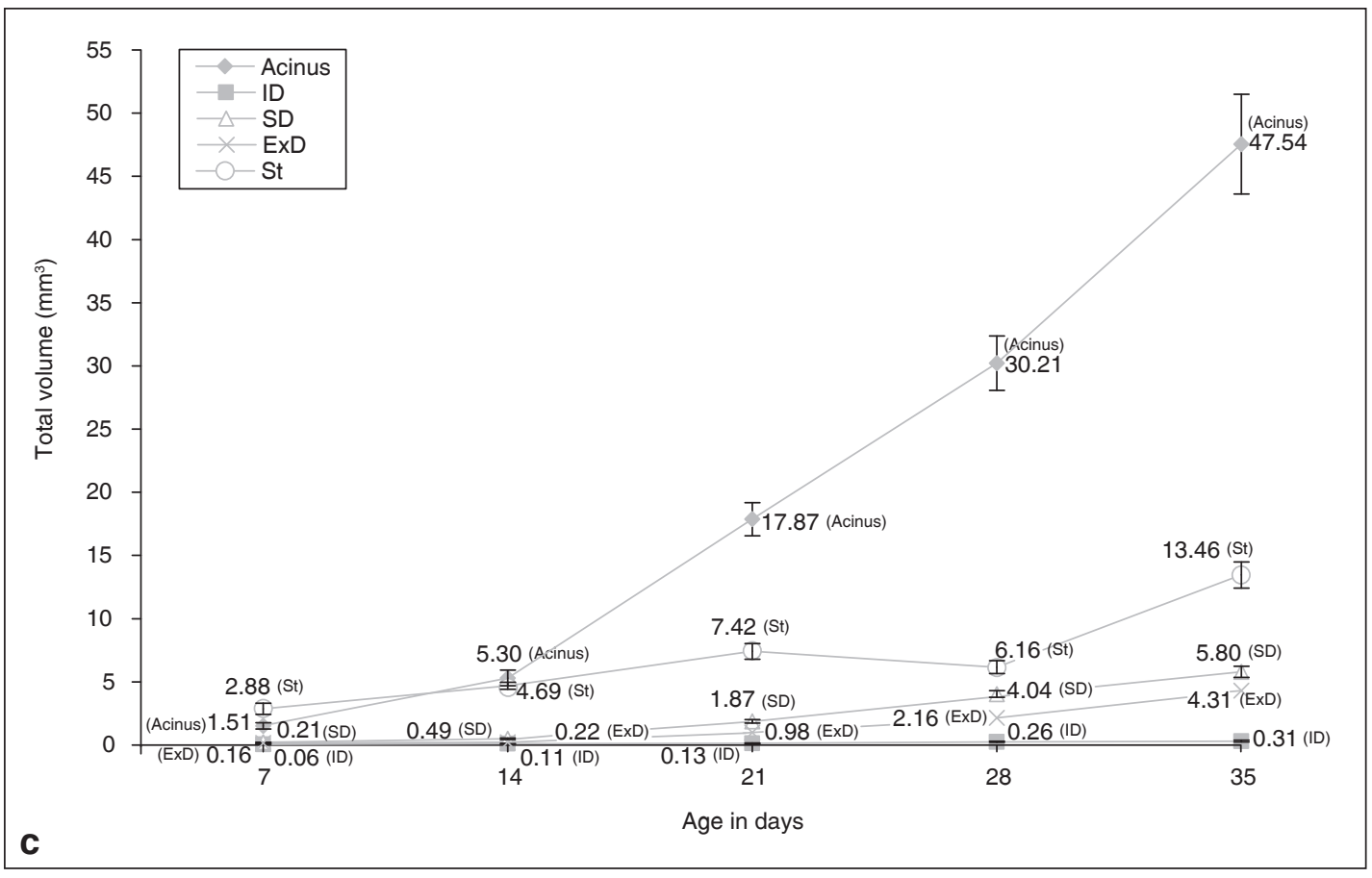

GRAPH 1c - Course of the absolute volume of the various structures of the mouse parotid gland. Legends: ID (Intercalated duct), SD (Striated duct), ExD (Excretory duct) and St (stroma). Mean of 6 animals per group and bars = standard error of mean. 
Ribeiro TTC, Sottovia AD, Cestari TM, Taga R. Morphometric study of the postnatal growth of the parotid gland of the mouse. Braz Oral Res 2006;20(1):13-20.

GRAPH 1d -

Course of the cell number of the various structures of the mouse parotid gland.

Legends: ID

(Intercalated duct), SD

(Striated duct),

ExD (Excretory duct) and St (stroma). Mean of 6 animals per group and bars $=$ standard error of mean.

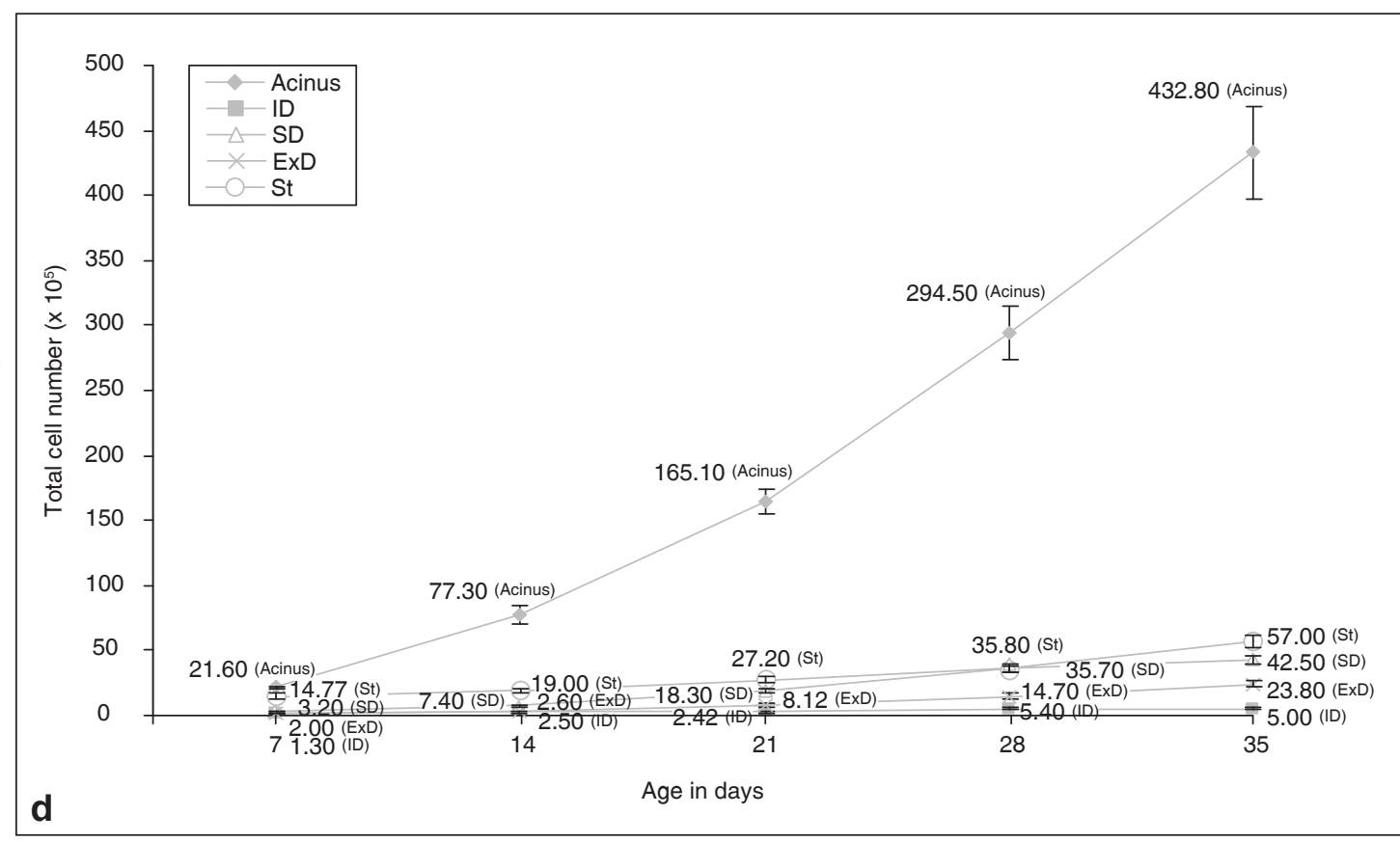

TABLE 1 - Exponential equations obtained by regression analysis for the growth of the parotid glands of the mouse during the first 35 days of age.

\begin{tabular}{c|l|c|c|c}
\hline \hline & \multicolumn{1}{|c|}{ Dimension } & \multicolumn{1}{|c|}{ Equation } & $\begin{array}{c}\text { Determination } \\
\text { coefficient }\left(\mathrm{r}^{2}\right)\end{array}$ & Duplication time $\left(\mathrm{T}_{\mathrm{D}}\right)$ \\
\hline \multirow{4}{*}{ Mass } & Body mass & $\mathrm{Y}=3.332 \mathrm{e}^{(0.060513 \mathrm{x})}$ & 0.981 & 11.45 days \\
\cline { 2 - 5 } & Gland mass & $\mathrm{Y}=5.588 \mathrm{e}^{(0.097593 \mathrm{x})}$ & 0.975 & 7.10 days \\
\hline \multirow{4}{*}{$\begin{array}{c}\text { Compartmenta } \\
\text { volume }\end{array}$} & Acinus & $\mathrm{Y}=0.865 \mathrm{e}^{(0.12342 \mathrm{x})}$ & 0.949 & 5.62 days \\
\cline { 2 - 5 } & Intercalated duct & $\mathrm{Y}=0.04245 \mathrm{e}^{(0.059209 \mathrm{x})}$ & 0.963 & 11.71 days \\
\cline { 2 - 5 } & Striated duct & $\mathrm{Y}=0.0980 \mathrm{e}^{(0.12495 \mathrm{x})}$ & 0.966 & 5.55 days \\
\cline { 2 - 5 } & Excretory duct & $\mathrm{Y}=0.05656 \mathrm{e}^{(0.12673 \mathrm{x})}$ & 0.969 & 14.45 days \\
\cline { 2 - 5 } $\begin{array}{c}\text { Total cell } \\
\text { number }\end{array}$ & Stroma & $\mathrm{Y}=2.2213 \mathrm{e}^{(0.04795 \mathrm{x})}$ & 0.868 & 6.62 days \\
\cline { 2 - 5 } & Acinus & $\mathrm{Y}=14.248 \mathrm{e}^{(0.104753 \mathrm{x})}$ & 0.972 & 20.40 days \\
\cline { 2 - 5 } & Striated duct & $\mathrm{Y}=1.926 \mathrm{e}^{(0.096379 \mathrm{x})}$ & 0.869 & 7.26 days \\
\cline { 2 - 5 } & Excretory duct & $\mathrm{Y}=0.918 \mathrm{e}^{(0.095506 \mathrm{x})}$ & 0.956 & 14.51 days \\
\cline { 2 - 5 } & Stroma & $\mathrm{Y}=10.055 \mathrm{e}^{(0.047770 \mathrm{x})}$ & 0.990 &
\end{tabular}

$1,228 \%, 1,090 \%$ and $286 \%$ for the acinar, intercalated duct, striated duct, excretory duct and stromal cell populations, respectively $(\mathrm{P}<0.01$ for all compartments).

The exponential equations obtained to mathematically express cell population growth in the different glandular compartments and the corresponding $T_{D}$ values are presented in Table 1 . It should be noted that, in this case, $T_{D}$ represents an estimate of the accumulation rate of new cells in the compartment. The duplication times in increasing order were $6.62,7.19,7.26,14.51$ and 20.4 days for the acinar, striated duct, excretory duct, stromal and intercalated duct cell populations, respectively.

\section{DISCUSSION}

In the present study, morphological analysis demonstrated that at one week after birth all epi- 
Ribeiro TTC, Sottovia AD, Cestari TM, Taga R. Morphometric study of the postnatal growth of the parotid gland of the mouse. Braz Oral Res 2006;20(1):13-20.

thelial structures present in the parenchyma of the adult animal, i.e., acini, intercalated ducts, striated ducts and excretory ducts, can be identified, although still completely immature. Confirming the morphological observations made by $\mathrm{Gabe}^{4}$ (1956) in mice and by Redman, Sreebny ${ }^{11,12}$ (1971, 1970) and Taga, Sesso ${ }^{19}$ (1979) in rats, we observed that the most conspicuous growth and maturation of these structures occurs during the first 4 weeks of postnatal development, reaching their almost definitive morphology at the end of this period.

The increase in the number and size of the different glandular structures led to a marked growth of $1,424 \%$ in fresh gland mass from day 7 to day 35 of age, with a duplication time of 7.10 days.

From day 7 to day 35 of age, the highest growth rates in the absolute volume of each glandular compartment, including the stroma, were observed for the acini, striated ducts and excretory ducts, with percental increases of 3,048\%, 2,662\% and $2,594 \%$, respectively, and duplication times calculated using the corresponding exponential equations of 5.62, 5.55 and 5.47 days, respectively. The intercalated ducts and stroma showed lower growth rates during this period, with percental increases of $417 \%$ and $367 \%$ and duplication times of 11.71 and 14.45 days, respectively.

Previous studies on rats have demonstrated that parotid gland growth is the result of an increase in the absolute number of cells, due to proliferative activity ${ }^{17}$, and in the individual volume of the parenchymatous cells, especially acinar cells ${ }^{3}$.

In the present study, analysis of the course of the cell population of each glandular compartment permitted us to estimate the cell accumulation rate for each compartment, i.e., acini, intercalated ducts, striated ducts, excretory ducts and stroma. This estimate was obtained by calculating the duplication time for each cell population using the equation that better fitted the number of cells to age in days. Percental growth of the number of cells in the above compartments from day 7 to day 35 of age was $1,904 \%, 285 \%, 1,228 \%, 1,090 \%$ and $286 \%$, and the duplication time was $6.62,20.40$, $7.19,7.26$ and 14.51 days, respectively, i.e., the growth rates of the acinar, striated and excretory duct cell populations were similar but markedly higher than those of the intercalated duct and stromal cell populations.

Another fact worth mentioning was the relatively low cell accumulation rate in the intercalated ducts compartment during postnatal development of the mouse parotid glands, since several autoradiographic studies, using $\mathrm{H}^{3}$-thymidine labeling, have shown that the intercalated ducts of the rat parotid glands ${ }^{17}$, the submandibular glands of the rat $^{2}$ and mouse ${ }^{14}$, and the rat sublingual glands ${ }^{18}$ exhibit very high proliferation rates during postnatal development, which are significantly higher than that of the striated ducts.

However, despite the high proliferation rates observed for these glands, the intercalated duct cell population showed a markedly lower growth rate than the striated ducts, i.e., the accumulation of new cells in the intercalated duct compartment during the first months of life was lower than in the striated duct compartment. This fact has led these researchers to put forward the hypothesis that new cells produced in excess in the intercalated ducts of these glands migrate to the striated ducts, a process during which they undergo final morphological differentiation ${ }^{2,14,16,17}$.

Based on the present results showing growth patterns of the intercalated and striated duct cell populations similar to those reported in the studies cited above, we suggest that the same events may occur in the mouse parotid glands during early postnatal development, i.e., the intercalated duct compartment produces a relative excess of cells which are provided to the striated duct compartment.

\section{CONCLUSIONS}

The results obtained here permitted to conclude that the growth of the mouse parotid glands from day 7 to day 35 of age occurred by intense cell accumulation mainly in the acini, striated ducts and excretory ducts, with growth rates sensibly higher than those of the intercalated ducts and stroma. Comparison between the percental growth of compartmental volume and of absolute cell number suggested that the increase in the individual cell size also could have important participation in the growth of this gland growth.

\section{ACKNOWLEDGMENTS}

The study was supported by the State of São Paulo Research Foundation - FAPESP (Process no. 99/11597-9, 99/1174-9 and 98/11744-9). 
Ribeiro TTC, Sottovia AD, Cestari TM, Taga R. Morphometric study of the postnatal growth of the parotid gland of the mouse. Braz Oral Res 2006;20(1):13-20.

\section{REFERENCES}

1. Aherne W, Dunnill MS. Morphometry. London: Edward Arnold; 1982.

2. Alvares EP, Sesso A. Cell proliferation, differentiation and transformation in rat submandibular gland during early postnatal growth: a quantitative and morphological study. Arch Histol Jpn 1975;38(3):177-208.

3. Ferreira RR, Assis GF, Taga R. Estudo morfométrico da evolução do volume nuclear e citoplasmático e da relação citoplasma/núcleo de células acinosas de glândulas parótidas de rato durante a vida pós-natal. Rev Bras Cienc Morfol 1994;11(2):142-8.

4. Gabe M. Contribution à l'histogénese des glandes salivaires chez la souris albinos. Z Zellforsch Mikrosk Anat 1956;45(1):74-95.

5. Klein RM. Acinar cell proliferation in the parotid and submandibular salivary glands of the neonatal rat. Cell Tissue Kinet 1982;15(2):187-95.

6. Klein RM. Alteration of neonatal rat parotid gland acinar cell proliferation by guandethidine-induced sympathectomy. Cell Tissue Kinet 1979;12(4):411-23.

7. Klein RM, Harrington DB, Piliero SJ. Isoproterenol-induced changes in cell cycle kinetics of parotid gland acinar cells in 8-day-old rats. J Dent Res 1976;55(4):611-6.

8. Onofre MA, de Souza LB, Campos A Jr, Taga R. Stereological study of acinar growth in the rat parotid gland induced by isoproterenol. Arch Oral Biol 1997;42(5):333-8.

9. Onofre MA, Taga R. Crescimento de glândulas salivares maiores de roedores induzido pelo isoproterenol: uma revisão. Rev FOB 1995;3(1-4):61-70.

10. Redman RS. Proliferative activity by cell type in the developing rat parotid gland. Anat Rec 1995;241(4):52940 .
11. Redman RS, Sreebny LM. Morphologic and biochemical observations on the development of the rat parotid gland. Dev Biol 1971;25(2):248-79.

12. Redman RS, Sreebny LM. Proliferative behavior of differentiating cells in the developing rat parotid gland. J Cell Biol 1970;46(1):81-7.

13. Sesso A, Abrahamsohn PA, Tsanaclis A. Acinar cell proliferation in the rat pancreas during early postnatal growth. Acta Physiol Lat Am 1973;23(1):37-50.

14. Srinivasan R, Chang WW. The postnatal development of the submandibular gland of the mouse. Cell Tissue Res 1979;198(2):363-71.

15. Taga R, Martini DS, Sesso A. Autoradiographic evaluation of the cell cycle parameters of the various cell categories of the parotid, submandibular and sublingual glands of the suckling rat. Okajimas Folia Anat Jpn 1994;70(6):25560.

16. Taga R, Sesso A. Avaliação do número de células de órgãos pela dosagem bioquímica de DNA em homogeneizados por contagem direta através de métodos morfométricos. Ciência e Cultura 1978;30(10):1232-6.

17. Taga R, Sesso A. Cell population growth in the rat parotid gland during postnatal development. Arch Oral Biol 2001;46(10):909-18.

18. Taga R, Sesso A. Postnatal development of the rat sublingual glands. A morphometric and radioautographic study. Arch Histol Cytol 1998;61(5):417-26.

19. Taga R, Sesso A. Ultrastructural studies on developing parotid gland of the rat at early postnatal periods. Arch Histol Jpn 1979;42(4):427-44.
Received for publication on Jul 18, 2005

Sent for alterations on Oct 18, 2005 Accepted for publication on Dec 05, 2005 